\title{
Malignant Histiocytosis: A Reassessment of Cases Formerly Classified as Histiocytic Neoplasms and Review of the Literature
}

\author{
R. Maarten Egeler, MD, PhD, Laura Schmitz, MD, Pieter Sonneveld, MD, PhD \\ Carlos Mannival, MD, and Mark E. Nesbit, MD
}

Malignant histiocytosis (MH) and true
histiocytic lymphoma (THL) are hematopoie-
tic malignancies of the mononuclear phago-
cytic system distinguished from each other
by clinical presentation and presumed cell
of origin. THL present as a localized mass
derived from the fixed tissue histiocyte
which may or may not disseminate. MH orig-
inates from the circulating monocyte or tis-
sue macrophage and is characterized by a
syndrome of systemic symptoms, pancy-
topenia, adenopathy, hepatosplenomegaly,
and wasting. The distinction between MH
and THL is at times arbitrary and overlap ex-
ists between these syndromes. The clinico-
pathologic studies that defined these enti-
ties were performed prior to the
development of immunophenotyping and
other molecular techniques currently used
to ensure proper classification of he-
matopoietic malignancies. Nine patients
from the University of Minnesota originally
diagnosed with MH were retrospectively an-
alyzed using a panel of antibodies reactive

against $\mathrm{T}$ cell, B cell, and myelomonocytic antigens. Only one patient was reclassified as a possible histiocytic malignancy after reevaluation. Similar immunophenotyping studies have also shown cases previously diagnosed as $\mathrm{MH}$ or THL express lymphoid antigens, and would now be classified as $\mathrm{Ki}-1$ positive anaplastic large cell lymphoma (ALCL) or some other hematopoietic neoplasm. These results indicate true histiocytic neoplasms are extremely rare, and previous concepts concerning clinical presentation and therapeutic outcome of the entities are inaccurate. In this paper we summarize the results of multiple retrospective analyses of cases previously diagnosed as $\mathrm{MH}$ or $\mathrm{THL}$, including our experience at University of Minnesota, to illustrate the overall rarity of these entities. The current literature on malignant histiocytic disorders is reviewed, and the clinical presentation of patients determined to have histiocytic malignancies using contemporary analytical techniques is discussed. 1995 Wiley-Liss, Inc.

Key words: malignant histiocytosis, anaplastic large cell lymphoma, neoplasm

\section{INTRODUCTION}

Tumors of presumed histiocytic origin are a controversial subset of hematopoietic malignancies including true histiocytic lymphoma (THL) and malignant histiocytosis (MH). THL is defined as a focal proliferation of malignant histiocytes which may or may not disseminate. $\mathrm{MH}$ is characterized a syndrome of fever, wasting, pancytopenia, hepatosplenomegaly, adenopathy, and a systemic proliferation of malignant histiocytes [1]. The disease occasionally presents with isolated involvement of the gastrointestinal tract [2]. The distinction between $\mathrm{MH}$ and THL is at times arbitrary and the clinical syndromes may merge.

The clinicopathologic studies which defined histiocytic neoplasms were performed prior to the development of immunologic and molecular techniques now used to properly classify hematopoietic malignancies. We evaluated nine patients from the University of Minnesota originally diagnosed with $\mathrm{MH}$ using a broad panel of antibod- ies reactive with $B$ cell, $T$ cell, and myelomonocytic antigens. Only one of nine patients analyzed was reclassified as a possible histiocytic malignancy [3]. Similar immunophenotyping studies also have shown most cases previously diagnosed as MH or THL by clinical and morphologic criteria are in fact $\mathrm{Ki}-1$ anaplastic large cell

From the Sophia Children's Hospital, Erasmus University, Rotterdam, The Netherlands (R.M.E.), Hennepin Medical County Medical Center, Minneapolis, Minnesota (L.S.), University of Minnesota School of Medicine, Minneapolis, Minnesota (R.M.E., L.S., C.M., M.E.N.), and Dijkzigt Hospital, Erasmus University, Rotterdam, The Netherlands (P.S.).

Received August 19, 1993; accepted May 31, 1994.

Address reprint requests to $\mathrm{R}$. Maarten Egeler, $\mathrm{MD}, \mathrm{PhD}$, Erasmus University Rotterdam, Sophia Children's Hospital/University Hospital Dijkzigt, Department of Pediatrics, Division Pediatric HematologyOncology, Dr. Molewaterplein 60, 3015 GJ Rotterdam, The Netherlands. 
TABLE I. Criteria Used for Diagnosis of True Malignant Histiocytosis

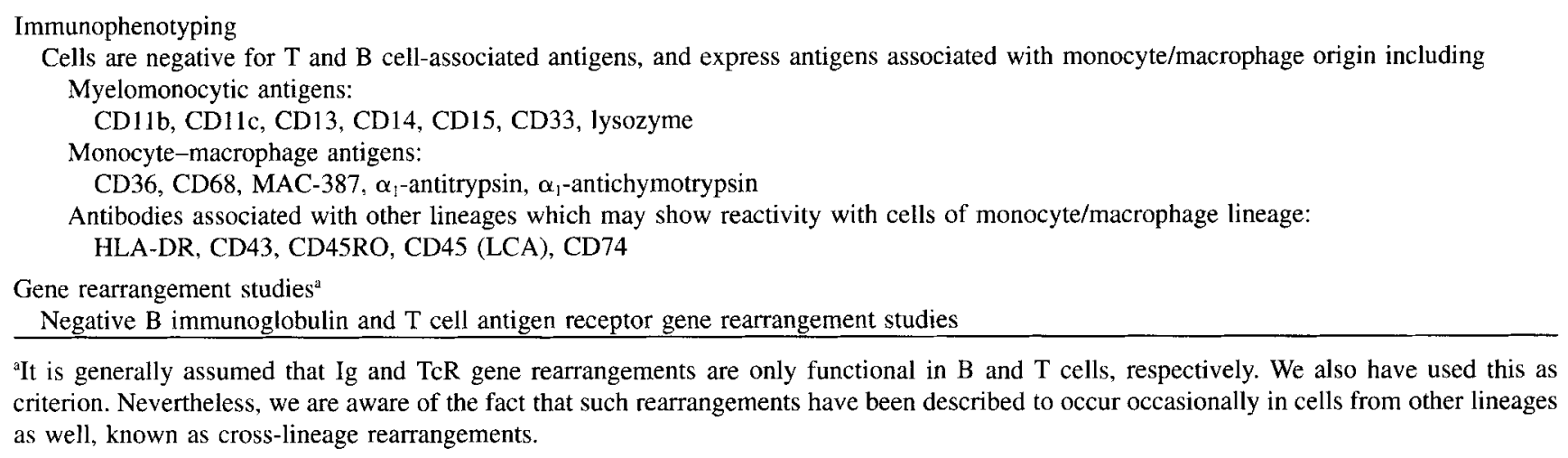

lymphoma (ALCL) or some other hematopoietic neoplasm [4-13]. While these results point to the rarity of these entities, sporadic cases exist which meet contemporary criteria for a malignant histiocytic disorder [14-18].

As most cases of $\mathrm{MH}$ and THL are now proven to be a heterogeneous group of other hematologic disorders, the clinical features traditionally associated with these syndromes should also be questioned. In this article we review the current literature on histiocytic malignancies, including our experience at University of Minnesota and other reevaluation studies, to illustrate the overall rarity of these neoplasms. The clinical presentation of patients determined to have true histiocytic malignancies by contemporary criteria are evaluated and discussed. Given the frequent overlap of these entities, the presenting feature of THL and MH will be discussed together under one category of true histiocytic malignancies.

\section{MATERIALS AND METHODS}

\section{Reevaluation of Patients From University of Minnesota Previously Diagnosed With Malignant Histiocytosis}

From 1967 to 199214 patients were diagnosed with $\mathrm{MH}$ at the University of Minnesota. The diagnosis was originally made by clinical examination, laboratory findings, radiographic studies, and morphologic interpretation of hematoxylin and eosin-stained biopsy sections.

In 1992 we reanalyzed the pathologic characteristics of these patients incorporating a large panel of immunoperoxidase antibody stains reactive against $\mathrm{B}$ cell, $\mathrm{T}$ cell, and myelomonocytic antigens on archival paraffinembedded tissue. Detailed results of this study are published elsewhere [3].

In brief, the antibodies used included CD30 (ber $\mathrm{H} 2 /$ Ki-1), EMA (epithelial cells, some lymphomas), CD45 (pan hematopietic), CD20 (B cell), CDw75 (B cell), CD74 (B cell), MB-2 (B cell), $\kappa, \lambda$, CD45RO ( $\mathrm{T}$ cell), CD3 ( $\mathrm{T}$ cell), MT-1 ( $\mathrm{T}$ cell), lysozyme (myelomono- cytic), $\alpha_{1}$-antitrypsin and $\alpha_{1}$-antichymotrypsin (monocyte/macrophage), CD68 (monocyte/macrophage), CD36 (monocyte/macrophage), CD15 (myelomonocytic, Reed Sternberg cells), and S-100 (neural origin cells, Langerhans cells). Frozen material for gene rearrangement studies was unavailable.

\section{Literature Review and Criteria for Inclusion as True Histiocytic Malignancy}

A medline computerized search was conducted to identify studies and case reports of MH or THL. Patients were determined to have a true histiocytic malignancy only when strict criteria was met as outlined by Weiss and others $[19,20]$ (Table I). Histiocytic malignancies are negative for pan B and T cell markers by immunophenotyping and show expression of multiple monocyte/ macrophage associated antigens including CD11b, CD11c, CD13, CD14, CD15, CD33, CD36, CD68, and MAC-387. Cytoplasmic enzymes such as $\alpha_{1}$-antitrypsin, $\alpha_{1}$-antichymotrypsin, or lysozyme are often present but are not specific enough to determine histiocytic lineage [16]. Isolated reactivity with antibodies associated with B or $\mathrm{T}$ lineage known to crossreact with cells of monocyte/ macrophage lineage is acceptable, but expression of multiple $\mathrm{B}$ or $\mathrm{T}$ cell markers suggests lymphoid lineage. When air-dried material is available, the cells are positive for nonspecific esterase, and negative for myeloperoxidase.

As lymphomas lacking $\mathrm{T}$ or $\mathrm{B}$ cell antigens, with or without expression of histiocytic markers, may show evidence of lymphoid lineage by gene rearrangement studies $[4,7,8,21]$, cases lacking gene rearrangement analysis were not included [22-27]. Patients developing acute monocytic leukemia after an initial diagnosis of $\mathrm{MH}$ or THL were excluded as these most likely represent granulocytic sarcomas $[28,29]$. Patients diagnosed with a malignant histocytic disorder who had evidence of $B$ or $T$ cell lineage by immunophenotyping or gene rearrangement studies were also excluded [30]. 


\section{RESULTS}

Reevaluation of Patients From University of Minnesota Previously Diagnosed With Malignant Histiocytosis

Nine of 14 patients diagnosed with $\mathrm{MH}$ at the University of Minnesota had complete clinical and pathologic data available for review. Eight of the nine patients originally diagnosed with $\mathrm{MH}$ were reclassified as having other hematologic malignancies based on the immunoperoxidase antibody studies. The results of this study are summarized in Table II and discussed below along with other reevaluation studies. One patient had a neoplasm of possible histiocytic origin by immunophenotyping. However, gene rearrangement studies were not performed and the true lineage is therefore uncertain.

\section{Summary of Literature Review of the Reevaluation Studies}

Eleven studies, including ours, have retrospectively analyzed and reclassified cases previously diagnosed as histiocytic malignancies using immunophenotyping or gene rearrangement analysis. The results of these studies are summarized in Table II. Approximately 164 cases of MH or THL have been analyzed with the majority of cases being reclassified into Ki-1 ALCL (114 cases), T or B cell lymphomas ( 24 cases), or some other category of hematopoietic disorder ( 7 cases). Nineteen cases retained the diagnosis of $\mathrm{MH} / \mathrm{THL}$ after reevaluation. These cases were negative for $B$ and $T$ cell markers and expressed monocyte-macrophage-associated antigens by immunophenotyping. Gene rearrangement studies, however, were not performed and the possibility of a B or $\mathrm{T}$ cell lymphoma cannot be ruled out. Nine cases were reclassified as $\mathrm{Ki}-1$ lymphoma of possible histiocytic lineage. These cases were negative for $B$ and $T$ cell markers and expressed monocyte-macrophage-associated antigens in addition to $\mathrm{CD} 30$ (Ki-1 antigen). With the exception of one case, gene rearrangement studies were not performed and a lymphoid lineage for these lesions cannot be ruled out [9]. Tumor cells in the case with gene rearrangement studies expressed histiocytic antigens and lacked evidence of $\mathrm{B}$ or $\mathrm{T}$ cell lineage by immunophenotyping or gene rearrangement studies. This case is discussed below under $\mathrm{Ki}-1$ positive lymphomas of possible histiocytic lineage.

Clinical Presentation of Patients With True Histiocytic Malignancies Determined by Contemporary Diagnostic Techniques

Application of the criteria for true histiocytic tumors to published cases of MH or THL reveals several cases which appear histiocytic in origin by immunophenotyping, but marked paucity of cases where B or $\mathrm{T}$ lineage has been excluded by gene rearrangement studies.
The clinical features of patients meeting all criteria for true histiocytic neoplasms are listed in Table III. Most patients presented with one or two sites of focal involvement with a high incidence of extranodal presentation. Cytopenias and systemic symptoms were sporadically noted. Hepatosplenomegaly was absent with isolated splenomegaly noted in 2 patients. Only one of seven patients presented with a clinical syndrome resembling MH including splenomegaly, lymphadenopathy, pancytopenia, fever, and systemic symptoms.

Of the several published studies excluded for lack of gene rearrangement analysis, two studies warrant further discussion given the large numbers of patients in those series. Sonneveld et al. [11] described 12 patients who retained the diagnosis of $\mathrm{MH}$ after reevaluation by immunoperoxidase studies. These patients presented with a clinical syndrome resembling $\mathrm{MH}$, including lymphadenopathy $(92 \%)$, splenomegaly $(100 \%)$, hepatomegaly (75\%), thrombocytopenia (92\%), anemia (92\%), leukocytopenia $(67 \%)$, and fever. A similar retrospective study of seven patients reclassified as MH by immunophenotyping reports a lower incidence of presenting features associated with MH [12]. All patiens had fever and generalized lymphadenopathy and $50 \%$ reported weight loss. Splenomegaly was noted in $42 \%$ and hepatosplenomegaly in $28 \%$. No comment was made on hematologic data. While these last two studies may represent true histiocytic neoplasms, generalizations concerning these data should be guarded. Gene rearrangement studies were not performed and a lymphoid lineage is not entirely ruled out.

\section{Clinical Presentation of Patients With CD30 positive (Ki-1 Associated Antigen) Lymphomas of Histiocytic Lineage by Contemporary Diagnostic Techniques}

Patients with $\mathrm{Ki}-1$ positive anaplastic lymphoma generally show evidence of $\mathrm{T}$ or $\mathrm{B}$ cell lineage with some patients demonstrating a mixed or indeterminate lineage. Review of the literature reveals an unusual subset of $\mathrm{CD}^{+} 0^{+}$lymphomas with expression of monocytemacrophage-associated antigens which lack evidence of T or B cell lineage by immunophenotyping or gene rearrangement studies $[9,15,31,32]$. The clinical features of this group were further evaluated to determine if this category of neoplasms is clinically unique.

As seen in Table IV, most patients presented with one or more sites of focal involvement with a high incidence of lymph node and extranodal involvement. Except for one patient, hepatosplenomegaly was not a feature of these patients and systemic features were sporadically reported. Hematologic data were not provided. One patient presented with a clinical syndrome resembling $\mathrm{MH}$ including hepatomegaly, lymphadenopathy, systemic symptoms, and a disseminated neoplasm. 
TABLE II. Results of Malignant Histiocytosis Reevaluation Studies*

\begin{tabular}{|c|c|c|c|}
\hline Reference & $\begin{array}{c}\text { Number of } \\
\text { cases }\end{array}$ & Method of reevaluation & New diagnosis \\
\hline Stein et al., $1985[4]^{a}$ & 45 & $\begin{array}{l}\text { Immunophenotyping, } \\
\text { limited gene } \\
\text { rearrangement studies }\end{array}$ & $\begin{array}{l}35 \mathrm{Ki}-1 \text { lymphoma, T cell type } \\
7 \mathrm{Ki}-1 \text { lymphoma, B cell type } \\
3 \mathrm{Ki}-1 \text { lymphoma, uncertain or } \\
\text { mixed lineage }\end{array}$ \\
\hline Weiss et al., $1985[5]^{b}$ & 6 & $\begin{array}{l}\text { Immunophenotyping, } \\
\text { gene rearrangement studies }\end{array}$ & $\begin{array}{l}4 \mathrm{~T} \text { cell lymphoma } \\
1 \mathrm{~B} \text { cell lymphoma } \\
1 \text { unclassified (possible IR) }\end{array}$ \\
\hline Isaccson et al., 1985 [6] & 4 & $\begin{array}{l}\text { Immunophenotyping } \\
\text { gene rearrangement studies }\end{array}$ & $\begin{array}{l}1 \text { unclassified } \\
3 \mathrm{~T} \text { cell lymphoma }\end{array}$ \\
\hline Delsol et al., $1988[7]^{\mathrm{c}}$ & 27 & Immunophenotyping & $\begin{array}{l}12 \mathrm{Ki}-1 \text { lymphoma, T cell type } \\
4 \mathrm{Ki}-1 \text { lymphoma, B cell type } \\
11 \mathrm{Ki}-1 \text { lymphoma, uncertain or } \\
\text { mixed lineage }\end{array}$ \\
\hline Cattoretti et al., 1990 [8] & 10 & $\begin{array}{l}\text { Immunophenotyping } \\
\text { gene rearrangement studies }\end{array}$ & $\begin{array}{l}5 \mathrm{~T} \text { cell lymphoma } \\
5 \mathrm{Ki}-1 \text { lymphoma, uncertain lineage }\end{array}$ \\
\hline Van der Valk et al., $1990[9]^{\mathrm{d}}$ & 12 & $\begin{array}{l}\text { Immunophenotyping } \\
\text { gene rearrangement studies }\end{array}$ & $\begin{array}{l}2 \mathrm{~B} \text { cell lymphomas } \\
1 \text { probable B cell lymphoma } \\
1 \mathrm{~T} \text { cell lymphoma } \\
1 \text { unclassified } \\
4 \mathrm{Ki}-1 \text { lymphoma, } \mathrm{T} \text { cell type } \\
2 \mathrm{Ki}-1 \text { lymphoma, probable } \mathrm{T} \text { cell type } \\
1 \mathrm{Ki}-1 \text { lymphoma, possible } \\
\quad \text { histiocytic lineage }\end{array}$ \\
\hline Wilson et al., $1990[10]$ & 15 & Immunophenotyping & $\begin{array}{l}3 \mathrm{~T} \text { cell lymphoma } \\
2 \mathrm{~B} \text { cell lymphoma } \\
6 \mathrm{Ki}-1 \text { lymphoma, } \mathrm{T} \text { cell type } \\
2 \mathrm{Ki}-1 \text { lymphoma, uncertain lineage } \\
1 \mathrm{IAHS} \\
1 \text { unclassified }\end{array}$ \\
\hline Sonneveld et al., $1990[11]^{\mathrm{e}}$ & 12 & Immunophenotyping & 12 malignant histiocytosis \\
\hline Hsu et al., $1991[12]^{\mathrm{f}}$ & 13 & $\begin{array}{l}\text { Immunophenotyping } \\
\text { limited gene } \\
\text { rearrangement studies }\end{array}$ & $\begin{array}{l}6 \text { malignant histiocytosis } \\
7 \mathrm{Ki}-1 \text { lymphoma, histiocytic lineage }\end{array}$ \\
\hline Nezelof et al., $1992[13]^{e}$ & 11 & Immunophenotyping & $\begin{array}{l}1 \mathrm{Ki}-1 \text { lymphoma, possible } \mathrm{T} \text { cell type } \\
9 \mathrm{Ki}-1 \text { lymphoma, histiocytic lineage } \\
1 \mathrm{unclassified} \text { (questionable } \\
\mathrm{Ki}-1 \text { positivity) }\end{array}$ \\
\hline Own patients [3] & 9 & Immunophenotyping & $\begin{array}{l}1 \mathrm{Ki}-1 \text { lymphoma, T cell type } \\
2 \mathrm{Ki}-1 \text { lymphoma, B cell type } \\
2 \mathrm{Ki}-1 \text { lymphoma, lineage indeterminate } \\
2 \mathrm{AML} \text { (FAB M5) } \\
1 \text { unclassified } \\
1 \text { possible histiocytic neoplasm }\end{array}$ \\
\hline
\end{tabular}

*IAHS, infectious associated hemophagocytic syndrome; IR, interdigitating reticulum cell.

${ }^{a}$ Majority of cases originally diagnosed as MH, exact number not stated. Evaluation for immunoglobulin heavy chain rearrangement only. ${ }^{\mathrm{h}} \mathrm{CD} 30$ studies were not done.

'Only 27 of 63 cases had complete immunophenotyping data. The exact number of these cases which were previously diagnosed as MH is not stated. "Includes one case of $\mathrm{Ki}-1$ positive lymphoma with expression of monocyte-macrophage numbers by immunophenotyping (IP) and lack of $\mathrm{T}$ cell or B cell differentiation by IP or gene rearrangement studies. This case is included in Table IV.

${ }^{\mathrm{e}}$ Possibility of $\mathrm{T}$ or $\mathrm{B}$ cell lineage not ruled out by gene rearrangement studies.

${ }^{\mathrm{f}}$ Malignant cells lack $\mathrm{T}$ and $\mathrm{B}$ cell markers and express histiocytic antigens. Gene rearrangement studies done in only 5 of 13 cases; exact cases not specified.

One study excluded from Table IV due to lack of gene rearrangement studies warrants further discussion given the large number of patients in this series [13]. The clinical features of 20 patients with $\mathrm{CD} 30^{+}$lymphoma of histiocytic lineage by immunophenotyping are described.
Patients in this group presented with a high incidence of lymphadenopathy (95\%) and systemic symptoms $(75 \%)$. Splenomegaly, hepatomegaly, and pancytopenia were noted in 30 to $40 \%$ of patients. As stated in the previous section, while cases from this study may represent 
TABLE III. Clinical Features at Presentation of Patients With Possible Histiocytic Malignancies*

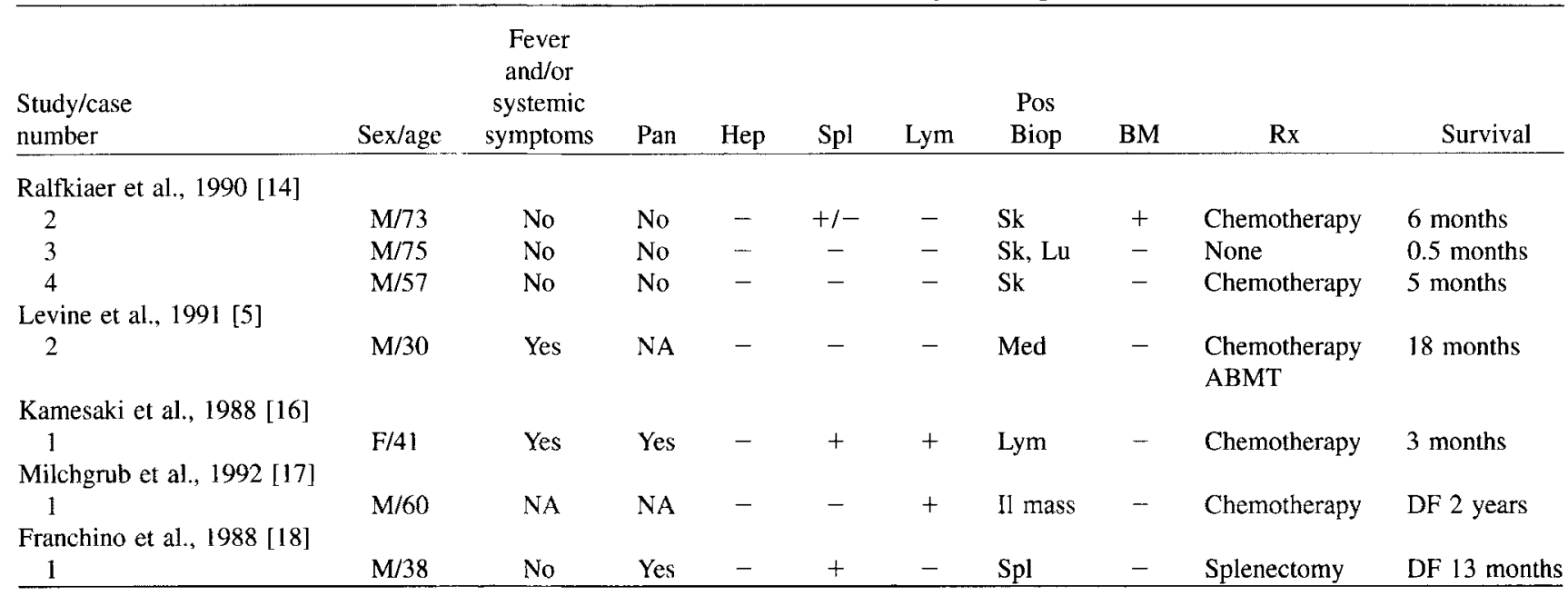

*Includes only patients with expression of monocyte-macrophage-associated antigens, lack of $\mathrm{T}$ or $\mathrm{B}$ cell antigens, and negative $\mathrm{T}$ and $\mathrm{B}$ cell gene rearrangement studies. Pan, pancytopenia; Hep, hepatomegaly; Spl, splenomegaly; Lym, lymphadenopathy; Pos Biop, positive biopsy; BM, bone marrow; Rx, treatment; Sk, skin; Lu, lungs; Med, mediastinum; Il, ileal; ABMT, autologous bone marrow transplantation; DF, disease free; NA, not addressed.

TABLE IV. Clinical Features at Presentation of Patients With Possible Histiocytic Malignancies Expressing CD30 (Ki-1)-Associated Antigen*

\begin{tabular}{|c|c|c|c|c|c|c|c|c|c|c|}
\hline $\begin{array}{l}\text { Study/case } \\
\text { number }\end{array}$ & Sex/age & $\begin{array}{c}\text { Fever } \\
\text { and/or } \\
\text { systemic } \\
\text { symptoms }\end{array}$ & Pan & Hep & Spl & Lym & $\begin{array}{l}\text { Pos } \\
\text { Biop }\end{array}$ & BM & $\mathrm{Rx}$ & Survival \\
\hline \multicolumn{11}{|l|}{ Levine et al., 1991 [15] } \\
\hline 4 & $\mathrm{~F} / 42$ & No & NA & - & - & + & $\begin{array}{l}\text { Gl mass } \\
\text { Lym }\end{array}$ & - & Chemotherapy & DF 4 months \\
\hline 6 & $M / 68$ & No & NA & - & - & + & $\begin{array}{l}\text { tongue } \\
\text { Lym }\end{array}$ & - & Chemotherapy & $\mathrm{Cr}, \mathrm{NA}$ \\
\hline 7 & $\mathrm{~F} / 10$ & No & NA & - & - & - & Sk & - & Chemotherapy & $\begin{array}{l}\text { Multiple } \\
\text { recurr } \\
8 \text { years }\end{array}$ \\
\hline Carbone et al., 1990 [31] & & & & & & & & & & \\
\hline $\begin{array}{l}2 \\
\text { Banks et al., } 1990 \text { [32] }\end{array}$ & $\mathrm{M} / 18$ & Yes & No & - & - & + & Lym & - & Chemotherapy & DF 23 months \\
\hline 1 & $\mathrm{~F} / 52$ & Yes & NA & + & - & + & $\begin{array}{r}\text { Lym, hep, } \\
\text { kidney, } \\
\text { ovaries }\end{array}$ & - & Chemotherapy & $\begin{array}{l}\text { Expired } \\
\text { no response } \\
\text { at all }\end{array}$ \\
\hline $\begin{array}{l}\text { Van der Valk et al., } 1990 \text { [9] } \\
10\end{array}$ & NA & NA & NA & NA & NA & NA & NA & NA & NA & NA \\
\hline
\end{tabular}

*Includes only cases with expression of monocyte-macrophage-associated antigens, lack of $\mathrm{T}$ or $\mathrm{B}$ cell antigens, and absence of $\mathrm{T}$ and $\mathrm{B}$ cell receptor and B cell immunoglobulin gene rearrangement. Pan, pancytopenia; Hep, hepatomegaly; Spl, splenomegaly; Lym, lymphadenopathy; Pos Biop, positive biopsy; BM, bone malrow; Rx, treatment; Sk, skin; Gl, gluteal; ABMT, autologous bone marrow transplantation; DF, disease free; NA, not addressed.

true histiocytic neoplasms, generalizations concerning these data should be guarded as B or T cell lineage is not ruled out.

\section{DISCUSSION}

The results of our study and multiple other studies analyzing archival tissue of cases previously diagnosed malignant histiocytosis/histiocytic lymphoma demonstrate the overall rarity of these entities. Prior to the availability of immunophenotyping and molecular techniques now used to classify hematopoietic neoplasms, MH was diagnosed on the basis of a syndrome of fever, wasting, pancytopenia, hepatosplenomegaly, lymphadenopathy, and a systemic proliferation of malignant appearing histiocytes. The majority of these cases are now 
known to be $\mathrm{Ki}-1$ anaplastic large cell lymphoma or some other hematologic disorder. The clinical features traditionally associated with histiocytic neoplasms should also be questioned and necessitates further evaluation.

While these studies demonstrate the overall rarity of MH and THL, a small number of cases exist in the literature which appear to be of histiocytic origin using current nosologic concepts of lymphoma and contemporary analytic techniques. These cases express surface antigens associated with monocyte-histiocyte origin and lack evidence of $\mathrm{T}$ or $\mathrm{B}$ cell lineage by immunophenotyping or gene rearrangement studies. A group of related neoplasms exists which appear to be of histiocytic origin but in addition express the $\mathrm{Ki}-1$-associated antigen. The presenting clinical features of these two groups were further evaluated to determine the clinical features associated with true histiocytic neoplasms diagnosed by contemporary techniques.

Although numbers are limited, the clinical presentation of patients with histiocytic neoplasms is heterogeneous and lacks a consistent clinical syndrome. These patients have one or more focal lesions with frequent extranodal proliferations. Fever, systemic symptoms, and cytopenias were sporadically reported. Patients with neoplasms of histiocytic lineage with CD30 antigen expression are similar and presented with one or more focal sites of involvement with frequent nodal and extranodal proliferations. Systemic symptoms were noted in two patients. Hematologic data were not given. Only one patient from each group presented with clinical features resembling $\mathrm{MH}$.

These results must be viewed as preliminary as large numbers of patients with histiocytic neoplasms by immunophenotyping were excluded from evaluation due to lack of gene rearrangement studies. We feel this exclusion criteria is valid as studies have shown lymphomas indeterminate for $B$ or $T$ cell lineage by immunophenotyping studies may have clonal $\mathrm{T}$ cell antigen or B cell immunoglobulin gene rearrangements. Some of these cases lacked $B$ and $T$ cell-associated antigens, express histiocytic antigens, and would have been misclassified as a histiocytic neoplasm in the absence of gene rearrangement studies $[5,8,9,21,33]$. We recognize that gene rearrangements are not specific exclusively to lymphoid lineage and occasional myeloid tumors show gene rearrangements. However, given the history of misdiagnosis of this entity, in this manuscript we recommended a diagnosis of MH/THL be made only in cases where immunophenotyping results support a histiocytic lineage and the cells lack T cell or B cell related gene rearrangements [19].

It is of interest that most cases previously diagnosed as $\mathrm{MH}$ are $\mathrm{Ki}-1$ positive anaplastic large cell lymphoma. While lymph node and/or skin involvement is the most common presentation of $\mathrm{Ki}-1$ lymphoma, a small subset of patients present with pancytopenia, hepatosplenomegaly, lymphadenopathy, fever, and wasting $[8,13,34]$. Some authors theorize the clinicopathologic syndrome previously described as MH may in fact represent a subset of $\mathrm{Ki}-1$ lymphoma, and suggests this subtype is recognizable on the basis of a $5 \mathrm{q} 35$ cytogenetic abnormality [35]. This theory is speculative and needs confirmation by further studies. Cases of $\mathrm{Ki}-1$ lymphoma have been reported with the $5 q 35$ cytogenetic abnormality which do not present with this syndrome [36,37].

The possibility that the present cases of histiocytic neoplasms may be related to a localized form of monocytic leukemia (AML M5b) cannot be excluded. It is known monocytic leukemia may present as a extramedullary mass without blood and marrow involvement [38-40]. Results of immunophenotyping and gene rearrangement studies would be similar in monocytic leukemia and histiocytic lymphomas. Morphologically AML M5b is composed of monoblasts, promonocytes, and monocytes. True histiocytic malignancies are reportedly composed of malignant appearing monocytes with greater variation in cell size and nuclear morphology $[1,14]$, a distinction which may be difficult and arbitrary. Careful consideration must be given to this possibility before a histiocytic neoplasm is diagnosed.

It is clear much work in the area of histiocytic malignancies remains to be done. A diagnosis of a true histiocytic neoplasm should not be considered unless strict pathologic criteria are met as outlined in this paper. Only until appropriate pathologic techniques are used on all cases can progress be made in identifying these patients and determining the cell of origin, the clinical presentation, appropriate treatment, and outcome. Once a unified approach in diagnosis is used the true nature of these neoplasms can be uncovered.

\section{REFERENCES}

1. Jaffe ES: Malignant histiocytosis and true histiocytic lymphomas. In: "Surgical Pathology of Lymph Nodes and Related Organs." Philadelphia, PA: W. B. Saunders, 1985, pp. 381-411.

2. Isaacson $P$, Wright $D$, Jones $D B$ : Malignant lymphoma of true histiocytic (monocyte/macrophage) origin. Cancer 51:80-91, 1983.

3. Schmitz L, Egeler RM, Nesbit ME, Mannival C: Malignant histiocytosis (true histiocytic lymphoma). Reevaluation of previously diagnosed cases at University of Minnesota. Document in preparation.

4. Stein H, Mason DY, Gerdes J, O'Connor J, Wainscoat J, Pallesen G, Gatter K, Falini B. Delsol G, Lemke H, Schwarting R, Lennert $\mathrm{K}$ : The expression of the Hodgkin's disease associated antigen $\mathrm{Ki}-1$ in reactive and neoplastic lymphoid tissue: Evidence that Reed-Stemberg cells and histiocytic malignancies are derived from activated lymphoid cells. Blood 66:848-858, 1985.

5. Weiss LM, Trela MJ, Cleary ML, Turner RR, Warnke RA, Sklar $\mathrm{J}$ : Frequent immunoglobulin and $\mathrm{T}$ cell receptor gene rearrangements in histiocytic neoplasms. Am J Pathol 121:369-373, 1985.

6. Isaccson PG, Spencer J, Connolly CE, Pollock DJ, Stein H, 
O'Connor NT, Bevan DH, Wainscoit JS, Mason DY: Malignant histiocytosis of the intestine: A T cell lymphoma. Lancet 2:688$691,1985$.

7. Delsol G, Al Saati T, Gatter KC: Gerdes J, Schwarting R, Caveriviere P, Rigal-Huguet F, Robert A, Stein H, Mason DY: Coexpression of epithelial membrane antigen (EMA), Ki-1, and interleukin-2 receptor by anaplastic large cell lymphomas. Diagnostic value in so-called malignant histiocytosis. Am J Pathol 130:59-70, 1988.

8. Cattoretti G, Villa A, Vezzoni P, Giardini R, Lombardi L, Rilke F: Malignant histiocytosis. A phenotypic and genotypic investigation. Am J Pathol 136:1009-1019, 1990.

9. Van der Valk P, van Oostveen JW, Stel HV, Van der Kwast TH, Melief CJ, Meijer CJ: Phenotypic and genotypic analysis of largecell lymphomas, formerly classified as true histiocytic lymphoma: Identification of an unusual group of tumors. Leuk Res 14:337346, 1990.

10. Wilson MS, Weiss LM, Gatter KC, Mason DY, Dorfman RF, Warnke RA: Malignant histiocytosis. A reassessment of cases previously reported in 1975 based on paraffin section immunophenotyping studies. Cancer 66:530-536, 1990.

11. Sonneveld P, van Lom K, Kappers-Klunne M, Prins ME, Abels J: Clinicopathological diagnosis and treatment of malignant histiocytosis. Br J Haematol 75:511-516, 1990.

12. Hsu S, Ho Y, Hsu P: Lymphomas of true histiocytic origin. Expression of different phenotypes in so-called true histiocytic lymphoma and malignant histiocylosis. Am J Pathol 138:13891404, 1991.

13. Nezelof C, Barbey S, Gogusev J, Terrier-Lacombe M-J: Malignant histiocytosis in childhood: A distinctive CD30-positive clinicopathological entity associated with a chromosomal translocation involving 5q35. Sem Diagn Pathol 9:75-89, 1992.

14. Ralfkiaer E, Delsol G, O'Connor N, Brandtzaeg P, Brousset P, Vejlsgaard G, Mason D: Malignant lymphomas of true histiocytic origin. A clinical, histological, immunophenotypic, and genotypic study. J Pathol 160:9-17, 1990.

15. Levine EG, Hanson CA, Jascz W, Peterson BA: True histiocytic lymphoma. Semin Oncol 18:39-49, 1991

16. Kamesaki H, Mitsuhiko K, Hiroshi M, Kita K, Doi S, Tatsumi E, Hatanaka M, Uchino H: Malignant histiocytosis with rearrangement of the heavy chain gene and evidence of monocyte-macrophage lineage. Cancer 62:1306-1304, 1988.

17. Milchgrub S, Kamel OW, Wiley E, Vuitch F, Cleary ML, Warnke RA: Malignant histiocytic neoplasms of the small intestine. Am J Surg Pathol 16:11-20, 1992.

18. Franchino C, Reich C, Distenfeld A, Ubriaco A, Knowles DM: A clinicopathologically distinctive primary splenic histiocytic neoplasm. Am J Surg Pathol 12:398-404, 1988.

19. Weiss LM: Histiocytic and dendritic cell proliferations. In: "Neoplastic Hematopathology." Baltimore, MD; Williams \& Wilkins, 1992, pp. 1459-1484.

20. Bucksky P, Favara B, Feller AC, Nezelof C, Radzun HJ, Schlegelberger B, Janka-Schaub G: Malignant histiocytosis and large cell anaplastic (Ki-1) lymphoma in childhood: Guidelines for differential diagnosis. Report of the Histiocyte Society. Med Pediatr Oncol 22:200-203, 1994.

21. Weiss LM, Picker LJ, Copenhaver CM, Warnke RA, Sklar J: Large-cell hematolymphoid neoplasms of uncertain lineage. Human Pathol 19:967-973, 1988.

22. Salyer J, Craven M: Malignant histiocytosis in a patient with acquired immunodeficiency syndrome-related complex. Arch Pathol Lab Med 114:376-378, 1990.

23. Koo C, Sheibani K, Marathe G, Rappaport H: True histiocytic lymphoma: An analysis of eight cases with multiparameter studies. Lab Invest 62:307(53-A), 1990.

24. Hibi S, Esumi N, Todo S, Imashuku S: Malignant histiocytosis in childhood: Clinical, cytochemical, and immunohistochemical studies of seven cases. Human Pathol 19:713-719, 1988.

25. Abe R, Akaike Y, Yokoyama A, Shikama Y, Ishibashi T, Mita $M$, Kimura $H$, Uchida $T$, Kariyone S, Wakasa $H$ : High incidence of $17 \mathrm{p} 13$ chromosomal abnormalities in malignant histiocytosis. Cancer 65:2689-2696, 1990.

26. Pileri S, Mazza P, Rivano M, Martinelli G, Cavazzini G, Gobbi M, Taruscio D, Lauria F, Tura S: Malignant histiocytosis (true histiocytic lymphoma). Clinicopathologic study of 25 cases. Histopathology 9:905-920, 1985.

27. Schifter T, Ga R, Deutsch D, Lewinski U: Uveitis, a presenting symptom of malignant histiocytosis. Haematologica 77:274-276, 1992.

28. Koo CH, Reifel J, Kogut N, Cove JK, Rappaport H: True histiocytic malignancy associated with a malignant teratoma in a patient with 46XY gonadal dysgenesis. Am J Surg Pathol 16:175-183, 1992.

29. Doll DC, Grogan TM, Greenberg BR: Chronic myelomonocytic leukemia terminating as malignant histiocytosis. Hematol Pathol 1:183-189, 1987.

30. Oka K, Mori N, Yatabe Y, Kojima M: Malignant histiocytosis: A report of three cases. Arch Pathol Lab Med 116:1228-1233, 1992.

31. Carbone A, Gloghini A, Valli DR, Tamaro P, Boiocchi BD, Volper K: Histopathologic, immunophenotypic, and genotypic analysis of $\mathrm{Ki}-1$ anaplastic large-cell lymphomas that express histiocyte-associated antigens. Cancer 66:2547-2556, 1990.

32. Banks P, Metter J, Allred C: Anaplastic large cell (Ki-1) lymphoma with histiocytic phenotype simulating carcinoma. Am J Clin Pathol 94:445-452, 1990.

33. O'Connor N, Stein H, Gatter K, Wainscoat JS, Crick J, Saati T, Falini B, Mason DY: Genotypic analysis of large cell lymphoma which express the $\mathrm{Ki}-1$ antigen. Histopathology 11:733-740, 1987.

34. Greer J, Kinney M, Collins R, Salhany KE, Wolff S, Hainsworth J, Flexner J, Stein R: Clinical features of 31 patients with Ki-1 anaplastic large-cell lymphoma. J Clin Oncol 9:539-547, 1991

35. Nezelof C: The $5 \mathrm{q} 35 \mathrm{bp}$ chromosomal abnormality characterizes certain CD30 positive anaplastic large cell lymphomas offering a new definition of malignant histiocytosis in childhood. Nouv Rev Fran Hematol 35:463 467, 1993.

36. Kaneko Y, Frizzera G, Edamura S, Maseki N, Sakurai M, Komada Y, Sakurai M, Tanaka H, Sasaki M, Suchi T, Kikuta A, Wakasa $H$, Hojo $H$, Mizutani $S$ : A novel translocation, $\mathrm{t}(2 ; 5)(\mathrm{p} 23 ; \mathrm{q} 35)$, in childhood phagocytic large T-cell lymphoma mimicking malignant histiocytosis. Blood 73:806-813, 1989.

37. Bitter MA, Franklin WA, Larson RA, McKeithan TW, Rubin CM, Le Beau MM, Stephen JK, Vardiman JW: Morphology in $\mathrm{Ki}-1$ (CD30)-positive non-Hodgkin's lymphoma is correlated with clinical features and presence of a unique chomosomal abnormality $\mathrm{t}(2 ; 5) 9 \mathrm{p} 23 ; \mathrm{q} 35)$. Am J Surg Pathol 14:305-316, 1990.

38. Odom LF, Lampkin BC, Tannous R, Buckley JD, Hammond GD: Acute monoblastic leukemia: A unique subtype-review from the Childrens Cancer Study Group. Leuk Res 14:1-10, 1990.

39. Scott CS, Stark AN, Limbert HJ, Head C: Diagnostic and prognostic factors in acute monocytic leukemia: An analysis of 51 cases. Br J Hematol 69:247-252, 1988.

40. Watanaba S, Fujimura M, Kashima M, Mozoguchi M, Takahash $\mathrm{H}$, Fujita A: Cutaneous involvement as a presenting feature of monocytic leukemia: Morphological and immunohistochemical studies. J Dermatol 17:609-617, 1990. 